\title{
PENDEKATAN HOLISTIK (HOLISTIC APPROACH) SEBAGAI UPAYA EFEKTIF PENGENTASAN KEMISKINAN: STUDI KASUS PADA TIGA KELUARGA MISKIN
}

\author{
RR. Lulus Prapti NSS. \\ Rahoyo \\ Dian Triyani
}

Diterima: Februari 2019, Disetujui: Maret 2019. Dipublikasikan: April 2019

\begin{abstract}
Various programs and government efforts to reduce poverty have indeed been rolled out, including Farmer Business Credit (1998) which reached Rp.8.4 trillion; Food Security Credit (2000) which reached 2.3 trillion; also the Kecamatan Development Program (PPK), the Urban Poverty Reduction Program (P2KP) and the Social Safety Net. However, the various efforts did not significantly reduce poverty. At least, the data above shows that from 2002 to 2007 the poverty rate remained perched at 16-18\% even though it was only one digit in 2018.

Of course we should not be pessimistic that poverty can indeed be suppressed and even eradicated. Muhammad Yunus, the 2006 Nobel Peace Prize winner, has proven it in Bangladesh. But, seeing the experience of the past 5 years, all efforts made by the government have not given significant results.

Another question that arises, why are all programs that have absorbed the trillions of costs unable to have a significant impact on efforts to alleviate poverty? Are emergent programs such as poor rice (raskin) and direct cash assistance (BLT) really a strategic approach to poverty alleviation?

This paper seeks to capture the lives of three poor families, Suji (65 years), Harni (55 years) and Subadi (61 years) as a case study. From what description they have about their lives, an analysis will be carried out to find out aspects related to their poverty.
\end{abstract}

Keywords: holistic approach, poverty

\begin{abstract}
Abstrak
Berbagai program dan upaya pemerintah untuk mengurangi angka kemiskinan memang pernah digulirkan, antara lain Kredit Usaha Tani (1998) yang mencapai Rp8,4 triliun; Kredit Ketahanan Pangan (2000) yang mencapai 2,3 triliun; juga Program Pengembangan Kecamatan (PPK), Program Penanggulangan Kemiskinan di Perkotaan (P2KP) dan Jaring Pengaman Sosial. Namun, berbagai upaya itu pun toh tak cukup signifikan mengurangi angka kemiskinan. Setidaknya, data di atas menunjukkan bahwa sejak 2002 sampai dengan 2007 angka kemiskinan tetap bertengger pada angka 16 - 18\% sekalipun memang tinggal satu digit pada 2018. Tentu saja kita tidak boleh pesimis bahwa kemiskinan pada dasarnya memang bisa ditekan bahkan bisa dihapuskan. Muhammad Yunus, peraih Nobel Perdamaian 2006 telah membuktikannya di Bangladesh. Tetapi, melihat pengalaman selama 5 tahun terakhir, semua usaha yang dilakukan pemerintah belum memberikan hasil yang berarti.

Pertanyaan lain yang muncul, mengapa semua program yang telah menyedot triliunan biaya tersebut tidak mampu membawa dampak signifikan dalam upaya pengentasan kemiskinan? Apakah program-program tanggap darurat (emergent) semacam beras miskin (raskin) dan bantuan langsung tunai (BLT) memang merupakan pendekatan strategis untuk pengentasan kemiskinan?Makalah ini berusaha memotret apa adanya kehidupan tiga keluarga miskin masing-masing Suji (65 tahun), Harni (55 tahun) dan Subadi (61 tahun) sebagai studi kasus. Dari deskripsi apa adanya mengenai kehidupan mereka akan dilakukan analisis untuk mengetahui aspek-aspek yang terkait dengan kemiskinan mereka.
\end{abstract}

Kata kunci: pendekatan holistik, keluarga miskin 


\section{Pendahuluan}

Hantu kemiskinan tampaknya masih tetap akan menjadi momok gentayangan yang sangat mengkhawatirkan bagi pemerintah dan rakyat Indonesia. Tak kurang, World Bank berdasarkan hasil penelitiannya tahun 2006 terhadap kemiskinan di Indonesia memberikan catatan sinis mengenai jumlah penduduk Indonesia yang mengalami kemiskinan absolut.

"Jumlah penduduk yang berpenghasilan kurang dari AS\$2/hari hampir sama dengan total penduduk yang berpenghasilan kurang dari AS\$2/hari seluruh kawasan Asia Timur kecuali Cina."

Dalam kurun waktu 17 tahun angka kemiskinan absolut memang berhasil ditekan dari 40,7\% pada 1976 menjadi sekitar 11\% pada 2005 dan bahkan menjadi 9,82\% pada 2018. Tetapi, angka tersebut kembali melonjak sebagai akibat badai krisis ekonomi yang menghantam Indonesia pada 1997. Secara nominal, jumlah penduduk miskin di Indonesia tahun 2006 mencapai 40 juta jiwa dan pada Juni 2007 mencapai 37,17 jiwa dan turun menjadi 25,9 juta jiwa pada 2018.

Yang harus dicatat, angka-angka itu pun diperoleh hanya didasarkan pada segi pendapatan (income). Apabila kriteria kemiskinan juga didasarkan pada segi nonpendapatan, bisa dipastikan angka-angka tersebut akan menjadi semakin mencemaskan. Bank Dunia mencatat: 25\% anak usia Balita di Indonesia mengalami gizi buruk; angka kematian Ibu 307 per 100.000 kelahiran hidup (3x Vietnam dan 6x Cina dan Malaysia); jumlah anak usia 16 - 18 tahun yang lulus SLTP hanya mencapai angka 55\% (untuk penduduk miskin) dan 89\% (untuk penduduk kaya).

Memang, merujuk pada Strategi Nasional Penanggulangan Kemiskinan (SNPK), pemerintah Indonesia pada 2009 menargetkan angka kemiskinan akan turun hingga hanya menjadi 8,2\%; angka kematian ibu dari 307 per 100.000 kelahiran hidup (2006) menjadi 226 per 100.000 kelahiran hidup; dan angka partisipasi sekolah menengah menjadi 98,1\%. Pertanyaan pokoknya, apakah target tersebut sungguh realistis?

Berbagai program dan upaya pemerintah untuk mengurangi angka kemiskinan memang pernah digulirkan, antara lain Kredit Usaha Tani (1998) yang mencapai Rp8,4 triliun; Kredit Ketahanan Pangan (2000) yang mencapai 2,3 triliun; juga Program Pengembangan Kecamatan (PPK), Program Penanggulangan Kemiskinan di Perkotaan (P2KP) dan Jaring Pengaman Sosial. Namun, berbagai upaya itu pun toh tak cukup 
signifikan mengurangi angka kemiskinan. Setidaknya, data di atas menunjukkan bahwa sejak 2002 sampai dengan 2007 angka kemiskinan tetap bertengger pada angka 16 - 18\% sekalipun memang tinggal satu digit pada 2018.

Tentu saja kita tidak boleh pesimis bahwa kemiskinan pada dasarnya memang bisa ditekan bahkan bisa dihapuskan. Muhammad Yunus, peraih Nobel Perdamaian 2006 telah membuktikannya di Bangladesh. Tetapi, melihat pengalaman selama 5 tahun terakhir, semua usaha yang dilakukan pemerintah belum memberikan hasil yang berarti.

Pertanyaan lain yang muncul, mengapa semua program yang telah menyedot triliunan biaya tersebut tidak mampu membawa dampak signifikan dalam upaya pengentasan kemiskinan? Apakah program-program tanggap darurat (emergent) semacam beras miskin (raskin) dan bantuan langsung tunai (BLT) memang merupakan pendekatan strategis untuk pengentasan kemiskinan?

Makalah ini berusaha memotret apa adanya kehidupan tiga keluarga miskin masing-masing Suji (65 tahun), Harni (55 tahun) dan Subadi (61 tahun) sebagai studi kasus. Dari deskripsi apa adanya mengenai kehidupan mereka akan dilakukan analisis untuk mengetahui aspek-aspek yang terkait dengan kemiskinan mereka.

Untuk tujuan tersebut, penulis telah melakukan kunjungan dan wawancara langsung kepada ketiga narasumber. Kepada Ibu Suji dan Ibu Harni penulis melakukan kunjungan dan wawancara di rumahnya. Sedangkan kepada Bapak Subadi, wawancara dilakukan di tempat kerjanya di Brumbungan - Semarang.

\section{Potret Tiga Keluarga Miskin}

Suji, namanya! Janda beranak 4 anak ini tinggal di Desa Ngablak RT 02/05 Kabupaten Magelang. Tak ada pekerjaan tetap baginya. Sehari-hari ia bekerja serabutan, tergantung dari para tetangga yang meminta bantuannya. Bisa mencuci piring, bisa memanen sayuran, atau sekadar memijit. Justru karena itu, tak ada patokan pasti berapa penghasilan setiap harinya. Selain permintaan bantuan dari para tetangganya tidak bisa dipastikan setiap hari datang, sering kali para tetangganya tersebut memberinya uang tanpa standar tertentu. Kadang Rp10.000,00 kadang Rp25.000,00 tapi kadang juga hanya seliter beras. 
Suaminya telah meninggal sejak 37 tahun lalu saat anak bungsunya baru berumur sebulan. Slamet (alm), suaminya, adalah seorang supir truk dan meninggal karena kecelakaan.

Sejak mula kehidupan keluarga Suji memang kurang beruntung. Baik dirinya maupun suaminya sama-sama terlahir dari keluarga kurang mampu. Karena itulah, beberapa tahun setelah menikah ia dan suaminya sempat bertransmigrasi ke Sumatera. Namun, tak lama kemudian mereka terpaksa kembali ke Jawa karena mengaku tidak kuat hidup di daerah trans.

Sebenarnya ia pernah mencoba berdagang sayuran kecil-kecilan (eber-eber- Jw) di pasar. Tetapi, lantaran modalnya yang kelewat cekak ia tak mampu bertahan menghadapi kerasnya persaingan.

Sepeninggal suaminya, ia rela menjadi istri kedua-juga seorang supir. Keputusannya menjadi istri kedua seorang supir itu semata-mata didasari satu hal; "Sapa ngerti isa melu mangan," (siapa tahu bisa sekadar ikut makan) begitu kenangnya. Ya, sekadar ikut makan. Karena pada dasarnya suami keduanya - Suroso, namanya - juga tidak mampu memberikan uang berlebih.

Nasib keempat anaknya? Untunglah ketika itu biaya pendidikan keempat anaknya dari sejak kelas I SD ditanggung sponsor yang dicarikan gereja. Keempat-empatnya lulus SLTP. Kini keempat-empatnya telah berkeluarga ... sekaligus keempat-empatnya juga berprofesi sebagai supir truk seperti ayah mereka.

Berbeda dengan Suji, Harni sebenarnya pernah mengalami hidup lumayan mapan di Ambon. Ia memang berasal dari keluarga pas-pasan. Justru karena itu, begitu menikah ia dan suaminya mengadu nasib ke Kota Manise itu. Ia menjadi jurumasak di asrama Brimob Ambon. Selain itu, ia juga berjualan makanan di sana. "Di sana enak, Pak. Cari duit gampang. Apa saja bisa jadi uang!" ungkapnya. "Kalau cuma cari uang Rp100.000,00 sehari saja gampang!” sambungnya.

Tak mengherankan bila dari hasil kerjanya tersebut ia tanpa mengalami kesulitan bisa menyekolahkan anaknya hingga tamat STM (sekarang SMK).

Sayang, nasib berkata lain. Ketika kerusuhan Ambon meletus, terpaksa ia tinggalkan begitu saja semua harta bendanya yang telah susah-susah ia kumpulkan! Ia kembali ke kampung halamannya di Desa Dawung, Pudak Payung dengan hanya berbekal beberapa potong pakaian. "Waktu itu yang terpikir hanya menyelamatkan nyawa saja!" katanya. 
Sekembalinya dari Ambon, ia menumpang di rumah adiknya yang ekonominya juga pas-pasan. Kehidupan Harni menjadi semakin berat ketika suaminya harus meninggal karena kecelakaan di Rembang.

Untuk menghidupi dirinya dan seorang putranya, kini ia bekerja sebagai pembantu harian (pocokan) di rumah tetangganya dengan upah Rp60.000,000 seminggu. Harni mengaku, sebenarnya ia ingin sekali kembali berdagang, tetapi keinginan tersebut harus ia kubur dalam-dalam karena terbentur modal. Untunglah bahwa dengan bekal ijazah STM, anaknya bisa bekerja serabutan sebagai teknisi tower. Dengan begitu, ia merasa tidak terlalu terbeban untuk selalu memikirkan kehidupan anaknya.

Subadi berbeda lagi. Lelaki kelahiran Kudus 61 tahun lalu ini sehari-hari mengayuh becak di kawasan Brumbungan - Semarang. Pada dasarnya ia telah menekuni profesi ini sejak tahun 1970-an. Ia mengaku tak pernah berusaha atau mencoba mencari pekerjaan lain. "Garis hidup saya ini Mas, ya. jalani saja!" tukasnya saat ditanya mengapa tidak mencoba mencari pe-kerjaan lain.

Dari hasil keringatnya sejak pukul 07.00 sampai pukul 17.00 rata-rata lelaki yang tinggal di Tambak Boyo, Semarang ini bisa mengantongi Rp25.000,00 per hari. Suami Ngatiyem ini lalu merinci, "Dari Rp25.000,00 itu Rp15.000,00 untuk makan dan sewa becak Rp2000,00 per hari. Jadi, bersihnya yang bisa saya bawa pulang ke rumah ya Rp10.000,00,”. "Padahal, pengeluaran harian di rumah Rp15.000,00” lanjut Pak Badi.

Tekor? Kekurangan itu ditutup istrinya - Ngatiyem — yang bekerja sebagai tukang cuci keluarga dengan upah Rp10.000,00 per hari. Praktis, dari hasil sehari-hari keluarga Subadi hanya menyisakan uang Rp5.000,00/hari. “Uang itu untuk jaga-jaga, Mas... kalau ada tetangga mantu, sumbangan apa atau apa gitu!"

Ayah empat orang anak ini memang telah memiliki rumah sendiri. Tapi, itu bukan hasil keringatnya. Keempat anaknyalah yang telah bantingan membelikan rumah untuknya.

Nasib anak-anaknya memang lebih baik daripada ayahnya. Berkat ijazah SLTA yang mereka miliki, mereka bisa bekerja di sebuah distributor air minum dalam kemasan. "Ya... tidak menyesal Mas, waktu itu 2 becak saya jual untuk biaya sekolah. Untung juga selalu ada bantuan dari saudara-saudara untuk biaya sekolah. Mereka sekarang tidak harus hidup menderita seperti bapaknya," katanya. 


\section{Pembahasan}

Pada umumnya, dari sisi penyebab, dikenal tiga macam kemiskinan (absolut), yaitu kemiskinan struktural, kemiskinan kultural dan kemiskinan natural. Mar'ie Muhammad (mantan Menteri Keuangan Republik Indonesia) mendefinisikan kemiskinan absolut sebagai ketidakmampuan seseorang, suatu keluarga, dan sekelompok masyarakat untuk memenuhi kebutuhan-kebutuhan dasar (basic needs). Termasuk dalam kebutuhan-kebutuhan dasar tersebut adalah pangan maupun nonpangan, khususnya pendidikan dasar, kesehatan dasar, perumahan dan kebutuhan transportasi. Pendekatan yang biasa dipakai untuk mengukur kemiskinan ini adalah pendekatan kebutuhan dasar (basic need approach) dan daya beli (purchasing power approach) yang tercermin dalam pendapatan per kapita per hari.

Kemiskinan struktural adalah kemiskinan yang diderita oleh suatu golongan masyarakat yang entah secara langsung atau tidak langsung disebabkan oleh tatanan kelembagaan yang ada. Contoh kemiskinan struktural adalah petani di Indonesia. Tanah para petani di Indonesia pada umumnya sangat terbatas. Bahkan, banyak petani yang sama sekali tidak memiliki tanah sehingga sebutan yang tepat bagi mereka adalah buruh tani.

Keterbatasan kepemilikan tanah, harga jual gabah yang rendah sehingga penjualan hasil pertanian tak cukup mampu untuk bahkan sekadar menutup biaya produksinya membuat para petani terlilit kemiskinan dari hari ke hari. Semua itu terjadi karena tatanan kelembagaan (tata niaga) beras, khususnya, sangat dikendalikan sementara bantuan dan proteksi dari pemerintah terhadap sektor ini kurang terlihat. Tatanan institusional inilah yang kemudian menjerembabkan para petani dalam kemiskinan struktural.

Sementara kemiskinan kultural didefinisikan sebagai kemiskinan yang terjadi akibat faktor-faktor budaya sehingga seseorang atau sekelompok orang tidak mampu "berproduksi” secara maksimal. Sikap malas, tak mau bekerja keras, ketiadaan budaya menabung, kebiasaan hidup boros, misalnya, tak pelak merupakan salah satu penyebab kemiskinan. Semua penyebab itu bisa digolongkan dalam faktor kultural.

Satu hal lagi yang sering disebut sebagai salah satu penyebab kemiskinan absolut adalah faktor alamiah. Misalnya, tanah yang tandus dan miskin sumber daya alam, penduduk terlalu padat, cacat fisik sejak lahir, usia jompo, dsb. Sekalipun demikian, John Kenneth Galbraith telah memberikan bukti bahwa faktor-faktor alamiah kurang bisa 
dijadikan penjelasan mengenai terjadinya kemiskinan. Ia menunjuk Jepang, Singapura, Taiwan, Hongkong dan Korsel sebagai bukti. Secara alamiah negara-negara tersebut bukanlah negara-negara yang kaya akan sumber daya alam. Namun demikian, dalam kenyataannya, kelima negara di atas tidak termasuk negara miskin.

Bagaimana dengan kasus kemiskinan yang terjadi pada Suji, Harni, dan Subadi di atas? Berdasarkan pengamatan dan realitas yang mereka hidupi, tak bisa ditampik bahwa mereka hidup dalam kemiskinan absolut. Pertanyaannya, faktor apakah yang membuat mereka miskin: faktor struktur, kultur atau alam?

Menilik kisah yang mereka ceritakan, bisa dipastikan bahwa faktor struktural dan kultural memainkan peran atas kemiskinan yang mereka alami. Faktor struktural bisa ditunjuk, misalnya kebijakan negara yang tidak memberikan perlindungan dan proteksi serta bantuan memadai bagi mereka. Secara spesifik, masuknya sepeda motor-sepeda motor murah akibat dibukanya kran perdagangan bebas dan syarat-syarat pemberian kredit sepeda motor yang demikian mudah akibat persaingan yang ketat, sedikit-banyak sangat memukul penghasilan tukang becak, seperti Subadi. Tiadanya regulasi mengenai upah, jaminan kesehatan, dsb. bagi para buruh rumah tangga seperti Suji dan Harni juga membuat keduanya terlilit kemiskinan yang tak berujung-pangkal. Tiadanya akses memperoleh pinjaman mudah dan murah bagi Suji dan Harni yang sebenarnya memiliki potensi berdagang, juga menyumbang pada terjadinya kemiskinan mereka. Itulah beberapa faktor kultural yang bisa disebut.

Secara kultural, beberapa hal bisa ditunjuk sebagai penyebab dan pelanggeng kemiskinan mereka. Ungkapan Subadi untuk menerima nasib seolah-olah itulah garis hidupnya telah menutup kemungkinan dirinya bereksplorasi mencari kemungkinan pekerjaan lain yang mungkin sebenarnya lebih menjanjikan. Faktor kultural ini juga bisa kita telisik pada diri Suji, mungkin juga Harni. Mereka de facto tidak punya nilai tawar di hadapan orang-orang yang mereka bantu. Sebagaimana yang ada pada diri orang Jawa pada umumnya, mereka selalu rikuh-pakewuh bila, misalnya, harus menawar atau berterus terang minta bayaran lebih tinggi, apalagi kepada tetangganya.

\section{Kesimpulan}

Amat jarang — kalau tidak dikatakan tidak ada — kemiskinan terjadi karena faktor tunggal (single factor). Bahkan dalam sudut pandang antropologis, antara kultur kemiskinan (culture of poverty) dan kemiskinan kultural (cultural poverty) sering 
jalin-menjalin sehingga hampir tidak mungkin kita memisahkan manakah sebab dan manakah akibat, sekalipun secara definitif keduanya ada pada kemiskinan. Yang tidak mungkin ditolak adalah bahwa mentransformasi kultur merupakan salah satu cara paling efektif untuk memutuskan mata rantai kemiskinan kultural. Dalam hal ini, pendidikan merupakan satu-satunya jalan untuk itu. Hanya dengan pendidikan wawasan seseorang akan terbuka dan hanya dengan terbukanya wawasan orang akan mampu mentransformasi diri, termasuk kebudayaannya.

Sedangkan secara struktural, jelas diperlukan good will pemerintah untuk memihak kepada yang lemah. John Stuart Mill dalam teori ekonominya membedakan antara produksi dan distribusi. Menyangkut produksi, Mill menyatakan bahwa hal tersebut memang sangat dipengaruhi oleh natural. Tetapi, soal distribusi, itu semata-mata menyangkut human will. Dan, dalam banyak hal, kemiskinan juga merupakan akibat tidak adilnya distribusi pendapatan dan pelayanan. Dalam konteks inilah, good will pemerintah untuk sepenuh hati membuka kesempatan yang adil kepada yang lemah guna mendapatkan akses keuangan (capital) dan pelayanan pembangunan menjadi faktor amat penting bagi penghapusan kemiskinan.

Dengan demikian jelaslah bahwa kemiskinan hanya akan tertangani secara efektif bila pemerintah dengan seluruh jajarannya didukung oleh seluruh komponen bangsa yang ada memiliki keberanian yang bulat untuk menangani kemiskinan tidak secara parsial, tetapi secara holistik. Semoga!

\section{Daftar Pustaka}

Bank Dunia. 2006. Era Baru dalam Pengentasan Kemiskinan di Indonesia. Jakarta: Bank Dunia.

Combs, Philip H dan Manzoor Ahmed. 1974. Memerangi Kemiskinan di Pedesaan Melalui Pendidikan Nonformal. Jakarta: CV Rajawali.

Galbraith, John Kenneth. 1979. Hakikat Kemiskinan Massa (terj. oleh Tom Anwar). Jakarta: Sinar Harapan

Mubyarto. 1987. Ekonomi Pancasila. Jakarta: LP3ES.

Sumodiningrat, Gunawan. 1999. Pemberdayaan Masyarat \& JPS. Jakarta: Gramedia Pustaka Utama. 
Majalah Ilmiah Solusi

Vol. 17, No. 2 April 2019

ISSN : 1412-5331

Suparlan, Parsudi (ed). 1993. Kemiskinan di Perkotaan: Bacaan untuk Antropologi Perkotaan. Jakarta: Yayasan Obor Indonesia.

Koran Kompas.

Koran Pikiran Rakyat.

Koran Tempo. 
Majalah Ilmiah Solusi

Vol. 17, No. 2 April 2019

ISSN : 1412-5331

" Halaman ini sengaja di kosongkan " 